TOLERANSI ANTAR UMAT BERAGAMA DALAM MEMPERKOKOH

\title{
PERSATUAN DAN KESATUAN BANGSA
}

\author{
Elma Lufita Umara \\ Institut Ilmu Kesehatan STRADA Indonesia \\ elmaluvitaumaraumara@gmail.com
}

\begin{abstract}
Abstrak
Untuk tetap menjaga persatuan dan kesatuan bangsa Indonesia maka diperlukan kesadaran individu dan kesadaran kolektif sebagai wujud kesetiaan kepada negara. Secara individual harus memiliki kesadaran bahwa ada perbedaan di antara kehidupan manusia. Toleransi agama adalah toleransi yang menyangkut keyakinan yang berhubungan dengan akidah yaitu sikap lapang dada untuk memberi kesempatan pemeluk agama selain Islam beribadah menurut ketentuan agama yang diyakininya. Sedangkan, toleransi sosial berorientasi terhadap toleransi kemasyarakatan.
\end{abstract}

\section{Latar Belakang}

Bangsa Indonesia dikenal sebagai bangsa yang majemuk, ditandai dengan banyaknya etnis, suku, agama, bahasa, budaya, dan adat-istiadat. Untuk persoalan agama, negara Indonesia bukanlah sebuah negara teokrasi, melainkan secara konstitusional negara mewajibkan warganya untuk memeluk satu dari agama-agama yang diakui eksistensinya sebagaimana tercantum di dalam pasal 29 ayat (1) dan (2) UUD 1945. Negara memberi kebebasan kepada penduduk untuk memilih salah satu agama yang telah ada di Indonesia yaitu agama Islam, Kristen Protestan, Kristen Katolik, Hindu, Budha dan Konghuchu. Kenyataan ini dengan sendirinya memaksa negara untuk terlibat dalam menata kehidupan beragama. sangat penting artinya bagi agama-agama dan para pemeluknya karena telah memberi jaminan dan sarana keterlibatan umat di dalam mengisi dan memperkaya kehidupan berbangsa.

Tiap pemeluk agama mendapatkan kesempatan untuk menjalankan agama dan 
menciptakan kehidupan beragama sesuai dengan ajaran agama masingmasing. Pengembangan agama dan kehidupan beragama tidak boleh menjurus ke arah tumbuhnya pemikiran dan pemahaman agama yang sempit karena hal ini akan menimbulkan konflik antar agama. Sebagaimana yang diungkapkan oleh Abdul Kadir ( 1992 : 344) mengenai potensi integrasi akan terjadi apabila terdapat suasana keharmonisan hubungan dalam dinamika pergaulan terutama intern umat beragama dan antar umat beragama. Sebaliknya, potensi disintegrasi akan menjadi kenyataan apabila terdapat suasana saling curiga dan persaingan dalam dinamika baik intern umat beragama maupun antar umat beragama.

\section{Kasus/Masalah}

Dengan adanya toleransi maka akan dapat melestarikan persatuan dan kesatuan bangsa, mendukung dan menyukseskan pembangunan, serta menghilangkan kesenjangan. Hubungan antar umat beragama didasarkan pada prinsip persaudaraan yang baik, bekerjasama untuk menghadapi musuh dan membela golongan yang menderita. Prinsip mengenai toleransi antar umat beragama yaitu: (1) tidak boleh ada paksaan dalam beragama baik paksaan itu berupa halus maupun dilakukan secara kasar; (2) manusia berhak untuk memilih dan memeluk agama yang diyakininya dan beribadat menurut keyakinan itu; (3) tidak akan berguna memaksa seseorang agar mengikuti suatu keyakinan tertentu ; dan (4) Tuhan Yang Maha Esa tidak melarang hidup bermasyarakat dengan yang tidak sefaham atau tidak seagama, dengan harapan menghindari sikap saling bermusuhan ( Ali, 1986: 82). Bentuk toleransig yang harus ditegakkan yaitu: (1) toleransi agama dan (2) toleransi sosial.

Toleransi agama adalah toleransi yang menyangkut keyakinan yang berhubungan dengan akidah yaitu sikap lapang dada untuk memberi kesempatan pemeluk agama selain Islam beribadah menurut ketentuan agama yang diyakininya.Sedangkan, toleransi sosial berorientasi terhadap toleransi kemasyarakatan. Dalam masyarakat yang beragam karena perbedaan agama dianjurkan untuk menegakkan kedamaian dan melakukan kerjasama dengan orang-orang yang berlainan agama dalam batas-batas yang telah ditentukan.Seluruh warga negara Indonesia (WNI) memiliki tugas dan tanggung jawab yang sama dalam memajukan bangsa. Pembangunan tidak akan tercapai secara optimal apabila tidak ada langkah maju yang sama antar elemen bangsa, termasuk di dalamnya adalah umat beragama. Oleh karena itu, kerjasama antara tokoh (umat) agama dan 
pemerintah (negara) menjadi sangat penting.

\section{Tinjauan Pustaka}

Untuk tetap menjaga persatuan dan kesatuan bangsa Indonesia maka diperlukan kesadaran individu dan kesadaran kolektif sebagai wujud kesetiaan kepada negara. Secara individual harus memiliki kesadaran bahwa ada perbedaan di antara kehidupan manusia. Kesadaran perbedaan ini kemudian diteruskan melalui dialog dan interaksi sosial untuk dapat saling memberi dan saling menerima dalam kesetaraan. Melalui kesadaran individual juga mencoba mencari dan merumuskan kesepakatan-kesepakatan sosial tanpa harus kehilangan jati diri dan karakteristik masingmasing. Inilah wujud dari

sikap toleransi yang saling menghormati dan menghargai dalam perbedaan. Sedangkan, kesadaran kolektif memandang konflik sosial merupakan hasil dari perbedaan kepentingan sosial, ekonomi dan politik yang berdampak adanya pelanggaran terhadap hak-hak sekelompok orang oleh kelompok orang yang lainnya. Untuk itu langkah struktural yang bersifat preventif yang dapat dilakukan dalam mengatasi konflik sosial, ekonomi dan politik bahkan dapat merembet ke persoalan konflik SARA adalah dengan membangun solidaritas sosial, kepedulian sosial dan interkasi sosial secara intensif.

\section{Pembahasan}

Secara normatif nilai-nilai dasar yang menjadi landasan terbentuknya toleransi antar umat beragama adalah sebagai berikut: Pertama adalah nilai agama yang bersumber dari ajaran yang terdapat pada masing-masing agama baik itu Islam maupun Kristen yang menjelaskan tentang pentingnya sikap toleransi antar umat beragama. Seperti ajaran agama Kristen yang berlandaskan pada hukum kasih yang berbunyi: (1) kasihilah Tuhan Allahmu dengan segenap hatimu dan segenap jiwamu, (2) kasihilah sesamamu seperti dirimu sendiri. Bahkan terhadap musuh pun harus saling mengasihi. Karena dengan mengembangkan sikap saling mengasihi maka akan menjadi anak-anak bapamu yang disurga.Sebagaimana yang dituturkan oleh Bapak Sarji S.TH (50 tahun) selaku Pendeta agama Kristen bahwa kasih sayang itu tidak hanya tercurahkan kepada Tuhan Yang Maha Esa, akan tetapi juga mangasihi terhadap sesama manusia, semua ciptaan Tuhan baik itu binatang, tumbuhan, tanah, air, batuan dan bahkan terhadap musuh harus mengasihi ( Matius 5: 44-45). Dengan terwujudnya ajaran cinta kasih maka akan menciptakan kerukunan hidup dengan tidak memandang perbedaan latar belakang 
agama, budaya maupun sosial. Jadi dalam ajaran agama Kristen telah mengatur toleransi dengan cara mengasihi Tuhan, sesama manusia dan bahkan musuh. Kasih kepada Tuhan dengan totalitas diri baik jiwa maupun raga. Kasih kepada sesama seperti mencintai diri sendiri dan tidak membeda-bedakan manusia berdasarkan latar budaya. Sementara kasih kepada musuh dengan cara mendoakan agar kembali kepada jalan yang lurus. Ajaran agama Kristen juga percaya bahwa semua agama itu mengajarkan tentang kebaikan, keluhuran budi dan kerukunan antar umat beragama.

Pada ajaran agama Islam pun telah mengatur tentang toleransi antar umat beragama. Seperti yang terdapat pada surat Al Kafirun ayat 6 yang berbunyi "Lakum Diinukum Waliyaddin" yang artinya untukmulah agamamu, dan untukkulah agamaku. Prinsip Islam mengenai toleransi adalah tidak seorang pun boleh dipaksa untuk memeluk agama lain dan atau meninggalkan ajaran agamanya, dan setiap orang berhak untuk beribadat menurut ketentuan agamanya masingmasing. Selain itu, ajaran agama Islam selalu mengingatkan manusia bahwa seluruh umat manusia diciptakan Allah berbeda-beda, karena dijadikan oleh-Nya berbangsa-bangsa dan bersukusuku. Semua itu tidak lain agar manusia saling mengenal dan saling menghormati. Manusia juga dianjurkan untuk beramal saleh terhadap siapapun agar mendapat pengampunan dan barokah. Kedua adalah nilai budaya yang lahir dari kebiasaan-kebiasaan yang dilakukan oleh sekelompok orang dan telah menjadi tradisi di lingkungan masyarakat tertentu. Misalkan kebiasaan gotong-royong, guyub rukun yang turut mewarnai kehidupan manusia.

\title{
5. Kesimpulan
}

Dengan adanya toleransi maka akan dapat melestarikan persatuan dan kesatuan bangsa, mendukung dan menyukseskan pembangunan, serta menghilangkan kesenjangan. Hubungan antar umat beragama didasarkan pada prinsip persaudaraan yang baik, bekerjasama untuk menghadapi musuh dan membela golongan yang menderita.

\section{Daftar Pustaka}

\author{
Ali, Mohammad Daud. 1986. Islam Untuk Disiplin \\ Ilmu Hukum, Sosial dan Politik. Jakarta: CV Wirabuana
}


Ihsan, Bakir. 2009. Menebar Toleransi Menyemai Harmoni. Bandung: PT Remaja Rosdakarya

Koentjaraningrat. 2002. Pengantar Ilmu Antropologi. Jakarta : PT. Rineka Cipta

Moleong, Lexi J. 2011. Metodologi Penelitian Kualitatif. Bandung: PT Remaja Rosdakarya

Sugiyono. 2011. Metode Penelitian Kuantitatif, Kualitatif, dan R\&D. Bandung: Alfabeta

Wahono, S.Wismoady. 2001. Pro-Eksistensi:

Kumpulan Tulisan untuk Mengacu Kehidupan Bersama. Jakarta : PT BPK Gunung Mulia

Hadisaputro, Muhda. 2002. Peranan Kerukunan Hidup Antar Umat Beragama Dalam Ketahanan Masyarakat.lib.ugm.ac.id/jurnal/download.php?datald=6666, diakses 